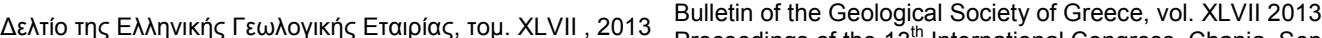
Proceedings of the $13^{\text {th }}$ International Congress, Chania, Sept.

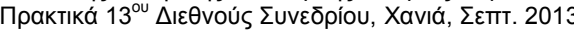
2013

\title{
WATER RESOURCES MANAGEMENT IN SPERCHIOS RIVER BASIN, USING SWOT ANALYSIS
}

\author{
Stathopoulos N. ${ }^{1}$, Rozos D. ${ }^{1}$ and Vasileiou E. ${ }^{1}$ \\ ${ }^{I}$ National Technical University of Athens, School of Mining Engineering \& Metallurgy, Section of \\ Geological Sciences, Laboratory of Engineering Geology \& Hydrogeology, \\ Iroon Polytechneiou 9, Zografou Campus,Athens 15780 \\ nstath@metal.ntua.gr,rozos@metal.ntua.gr,elvas@metal.ntua.gr
}

\begin{abstract}
SWOT (Strengths, Weaknesses, Opportunities and Threats) analysis is a useful tool for sustainable development and decision making about environmental planning and water resources management. This analysis was applied in order to evaluate the water resources of the wider area of Sperchios River.

Sperchios River basin, with an average altitude of approximately $810 \mathrm{~m}$, covers an area of $2116 \mathrm{~km}^{2}$. The river is recharged by many streams of permanent and periodic flow and discharges in Maliakos Gulf. The steep slopes, which are present within approximately $2 / 3$ of the total length of the river course, form a rather mountainous topography (streamy, with crucial flooding peaks and very intense sediment yield). Only in the last downstream part of Sperchios course, the topography gradually changes into a lowland relief, with an extent at the river mouth of $1830 \mathrm{~km}^{2}$. At this part of Sperchios severe cases of flooding have been occasionally observed and reported.

Regarding the SWOT applications on the wider area of Sperchios River, various data were processed (geological, meteorological, hydrological, hydrogeological, land use, socio-economic and environmental parameters) in order to suggest a water management planning in the area.

Key words: Maliakos Gulf, environmental pressures, sustainable management.
\end{abstract}

\section{Пєрí $\eta \psi \eta$}

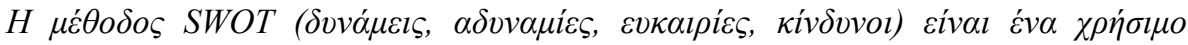

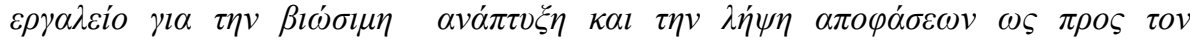

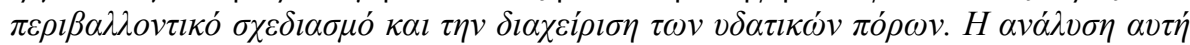

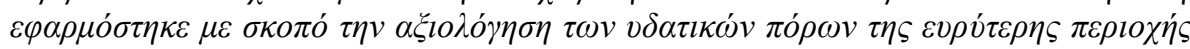

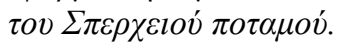

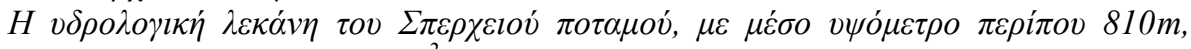

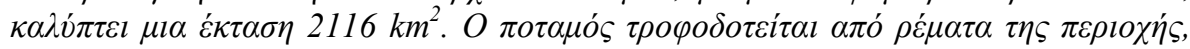

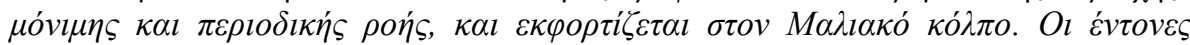

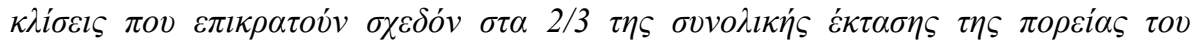

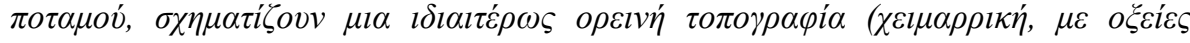

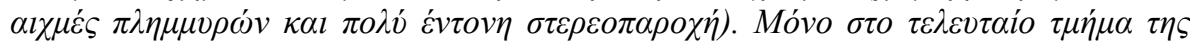

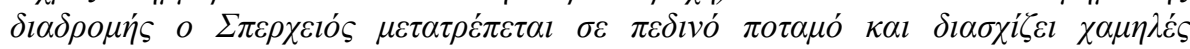




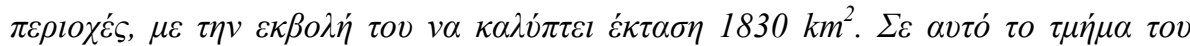

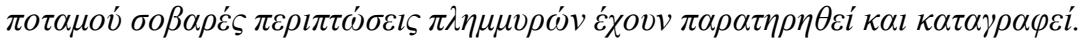

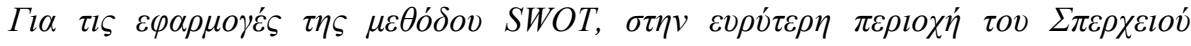

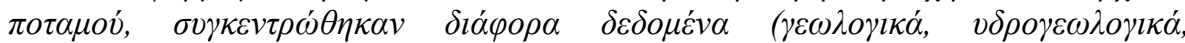

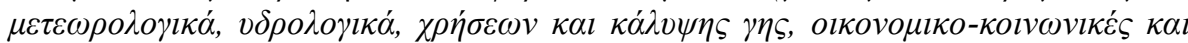

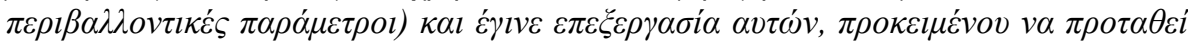

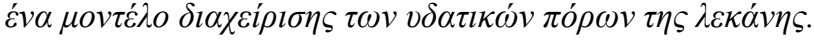

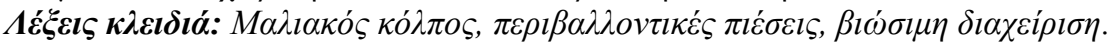

\section{Introduction}

Sperchios River basin extends from the east of Maliakos Gulf up to Tymfristos mountain in the west. From south the basin is delimited by the mountains Oiti and Kalidromo and from north by the mountain Orthris. The extent of the basin is almost $2116 \mathrm{~km}^{2}$, with an average altitude of $810 \mathrm{~m}$ (Kakavas, 1984).

Sperchios riverbed is recharged by streams of permanent and periodic flow. The river's valley, in the $2 / 3$ of its length, has steep slopes, which give to the river a rather mountainous - streamy character, with crucial flooding peaks and very intense sediment yield. On the contrary, at the last third of its course, Sperchios gradually transforms in a lowland river crossing low altitude areas, often causing severe flooding (Koutsogiannis, 2007).

The dominating land use of the basin is agriculture, therefore the water needs and mainly the irrigation needs are particularly increased. The proper water resources management of Sperchios basin is considered to be of high importance.

This paper constitutes a first approach in the area's water resources management via SWOT method analysis. The aim of this work is to locate all SWOT parameters in order a management model for water resources to be applied in the area of interest.

The conclusions and results of this paper are based on primary research that took place in the area, including conversations on targeted questions with citizens and local authorities, concerning the SWOT parameters that were evaluated as of great importance for this work.

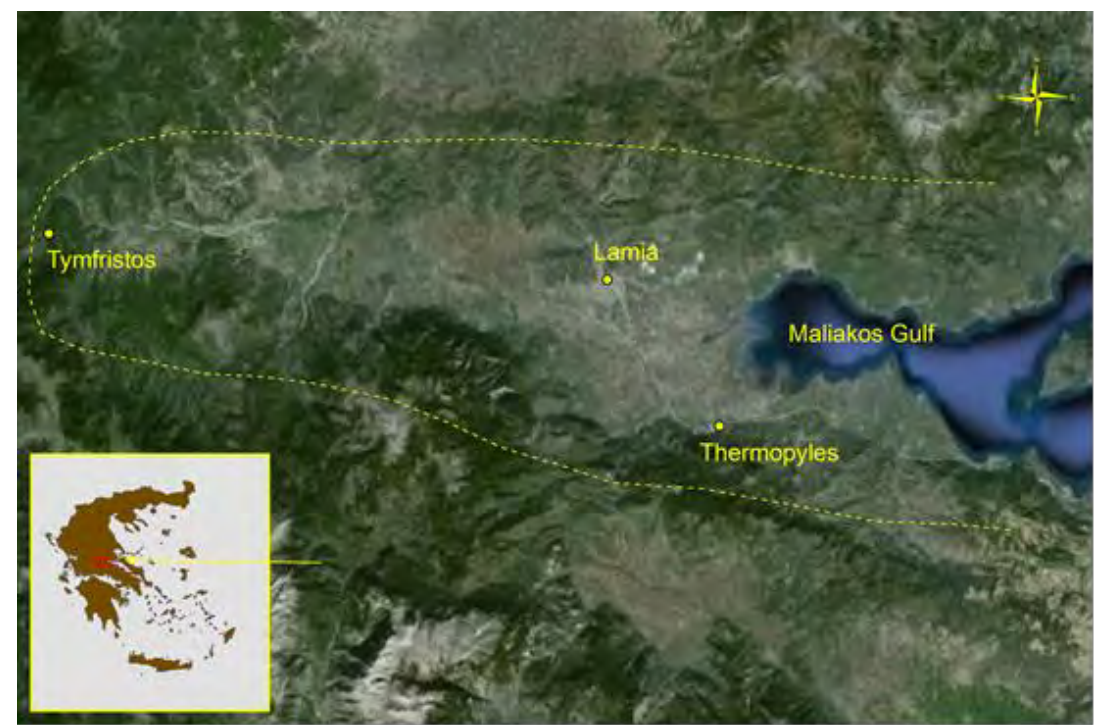

Figure 1 - Location of the study area.

XLVII. No $2-780$ 
Swot analysis is found to be a useful managerial tool, incorporating interdisciplinary issuesengineering, scientific, legislative, economic and social, which are difficult to quantify, in order to identify the main environmental problem of the study area, which is overexploitation of the groundwater resources (Kallioras et.al. 2010).

As groundwater becomes more critical, many countries increasingly face the challenges of multiple and competing stakeholders, competing uses of groundwater and variegated policy approaches for groundwater management (Kallioras et.al. 2010).

Groundwater is one of the most valuable natural resources in Greece, playing a vital role in the economy of the country. However, one could argue that this sensitive natural resource has been mismanaged during the last 60 years, which has led to a general qualitative as well as quantitative deterioration of the country's groundwater resources (Kallioras et. al., 2010).

Swot analysis is a form of market analysis introduced by Albert Humphrey at Stanford University in the 1960's and 1970s and is an acronym of its main components: strengths, weaknesses, opportunities and threats. It was subsequently applied as a general managerial tool in several scientific fields, including economics, law, environmental sciences and engineering, has been used in many case studies in water resources management and Engineering (Diamantopoulou and Voudouris, 2008).

\section{Methodology}

\subsection{Geological Data}

The creation of Sperchios basin is a result of tectonic movements, subsequent to the Alpine orogenesis cycle, mainly of faults of north - south and east - west direction. In the following time period the basin was filled with clastic sediments that came from the erosion of the basement's formations (IGME, 2010).

In the wider area, four unities of the Alpine orogenesis cycle are observed. North and southsoutheast the Subpelagonian zone, in the center and south the Parnassos - Giona zone and in the west Pindos zone and upper Pindos zone (IGME, 2010).

Lithologically, Sperchios basin is separated in three unities: a) in the west, where flysch and clastic formations of Pindos unity are found, b) in the north-northeast, where limestone, ophiolite and schist-crest formations of Parnassos - Giona zone are found, c) in the south southeast, where limestone of Parnassos - Giona zone is the dominating formation (Psomiadis E.,2010).

The central part of Sperchios basin is covered by Quaternary formations, which consist of river and land deposits, such as clays, sands, conglomerates, detrital cones, stream deposits and breccia, whose composition and spreading depend on the adjacent or subjacent older formations. In the areas where hot manifestations are observed, deposition of hot spring limestone is noticed (travertine) (IGME, 2010).

The Neogene sediments, continental, lacustrine or marine, which can be found in north-east and south-east part of Sperchios basin and mostly in the borders, consist of cohesive marl, siltstones, clays, conglomerates and marly limestone with small lignite insertions (IGME, 2010).

The basement consists mainly of schist, limestone, dolomite, ophiolite, schist-crest and flysch formations (IGME, 2010).

\subsection{Hydrogeology Data}

The formations of Sperchios basin present different hydrogeological characteristics, due to their lithological composition, porosity and water permeability. Based on these data the formations are separated in the following categories (Kakavas N., 1984): 
i. Permeable formations. This category includes carbonic rocks, conglomerates of lacustrine Pleistocene sediments, coarse materials of detrital cones, old and modern fanglomerates, as well as modern deposits of the riverbed.

ii. Semi-permeable up to permeable formations. This category includes the deep Sperchios delta deposits and the areas with alternations of sands, clays and grits, resulting in the creation of sub-confined and confined (artesian) aquifers. In addition, this category includes the ophiolite formations, as in this specific area they present increased permeability, due to secondary porosity caused by intense tectonism.

iii. Semi- permeable formations. This category includes the Quaternary deposits, consisting of mixed coarse and fine-grained materials. This heterogeneity develops limited and discontinuous aquifers. These formations are considered to be the flood deposits of Sperchios River, consisting of silt with layers of sand per places.

iv. Impermeable formations. In this category belong the formations that are considered to have permeability values from $10^{-6}$ up to $10^{-9} \mathrm{~m} / \mathrm{sec}$. Referring to the study area, these are the schist-crest and flysch formations beside the conglomerates and limestone layers, the older Sperchios deposits of silt-clays and the limestone tuffs of the thermal springs' deposits.

Two large categories of aquifers are distinguished in Sperchios basin (Kakavas N., 1984):

i. Aquifers deploying in the alluvial deposits, which are both unconfined and confined (artesian). The unconfined aquifer that is formed almost in the whole surface of the alluvial deposits is heterogeneous. Its capacity is characterized as moderate up to satisfactory. The confined aquifer is found in deeper layers and especially where frequent alternations of coarse and fine-grained materials exist.

ii. Aquifers of carbonic formations. The limestone formations of Orthris, Kalidromo and Oiti, are intensely tectonized, fragmented and karstified, with increased porosity and water permeability. Three karstic systems are being formed, of Lamia - Stylida, of Oiti and of Kalidromo - Oiti. The first system is discharged through Agia Paraskeui, Sfagia and Mauromantila springs, the second one through the spring complexion of Kompotades Meksiates and finally the last one through Mauroneria springs.

\subsection{Meteorological Data}

The climate ranges from dry to semi-humid. The average temperature is $16,8{ }^{\circ} \mathrm{C}$ in Lamia. The rainfall distribution at all stations is normal (figure 2), there is a linear regression between rainfall and the altitude in the area. The analysis of meteorological data showed decrease of rainfall (about $4 \mathrm{~mm} / \mathrm{yr}$ ) and runoff $(3 \mathrm{~mm} / \mathrm{yr})$. The annual rainfall in the area is about $893 \mathrm{~mm} / \mathrm{yr}$. In Lamia meteorological station, in the east coastal part of the area, the average precipitation is about 561 $\mathrm{mm}$. The total amount of evaporation is high, approximately $72 \%$, the infiltration and the surface runoff is $28 \%$. There is strong correlation between water table and discharge, as it is shown in figure 3 (Stathopoulos et. al, 2012).

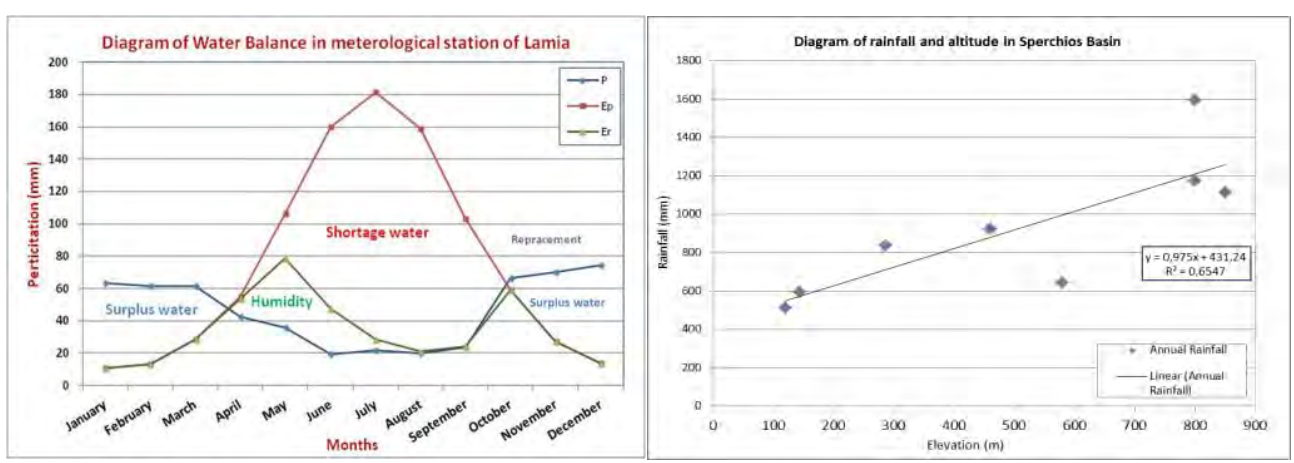

Figure 2 - Climatic diagram of water balance in Lamia and the correlation of rainfall and altitude (Stathopoulos et. al, 2012).

XLVII. No $2-782$ 


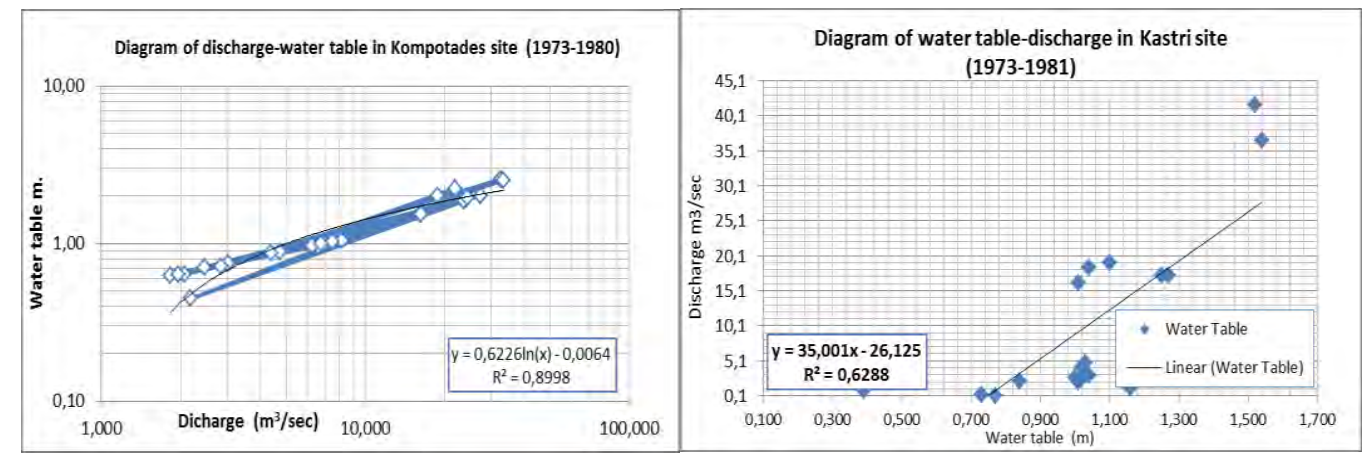

Figure 3 - Correlation diagram of water table and discharge in Kompotades and Kastri site (Stathopoulos et. al, 2012).

\subsection{Land Use and Land Cover}

Figure 4 presents the Land Cover map (Corine 2006) of the study area. As it can be noticed in table 1, the highest land cover percentage refers to hard leaf vegetation (about 20\%). The main Land uses are the agricultural areas with significant natural vegetation as well as and the complex cultivation systems.

\subsection{Water Quality Data}

Sperchios River is the natural runoff recipient of the wider part of agricultural areas in Fthiotida prefecture. The waste from the city of Lamia, after partial processing and carbon and nitrogen removal, as well as the processed waste of Lamia's industrial area, also end up in Sperchios River. Sperchios River in the upstream part of its course is of better quality, while in the downstream part it deteriorates gradually, with the highest deterioration occurring in the deltaic part.

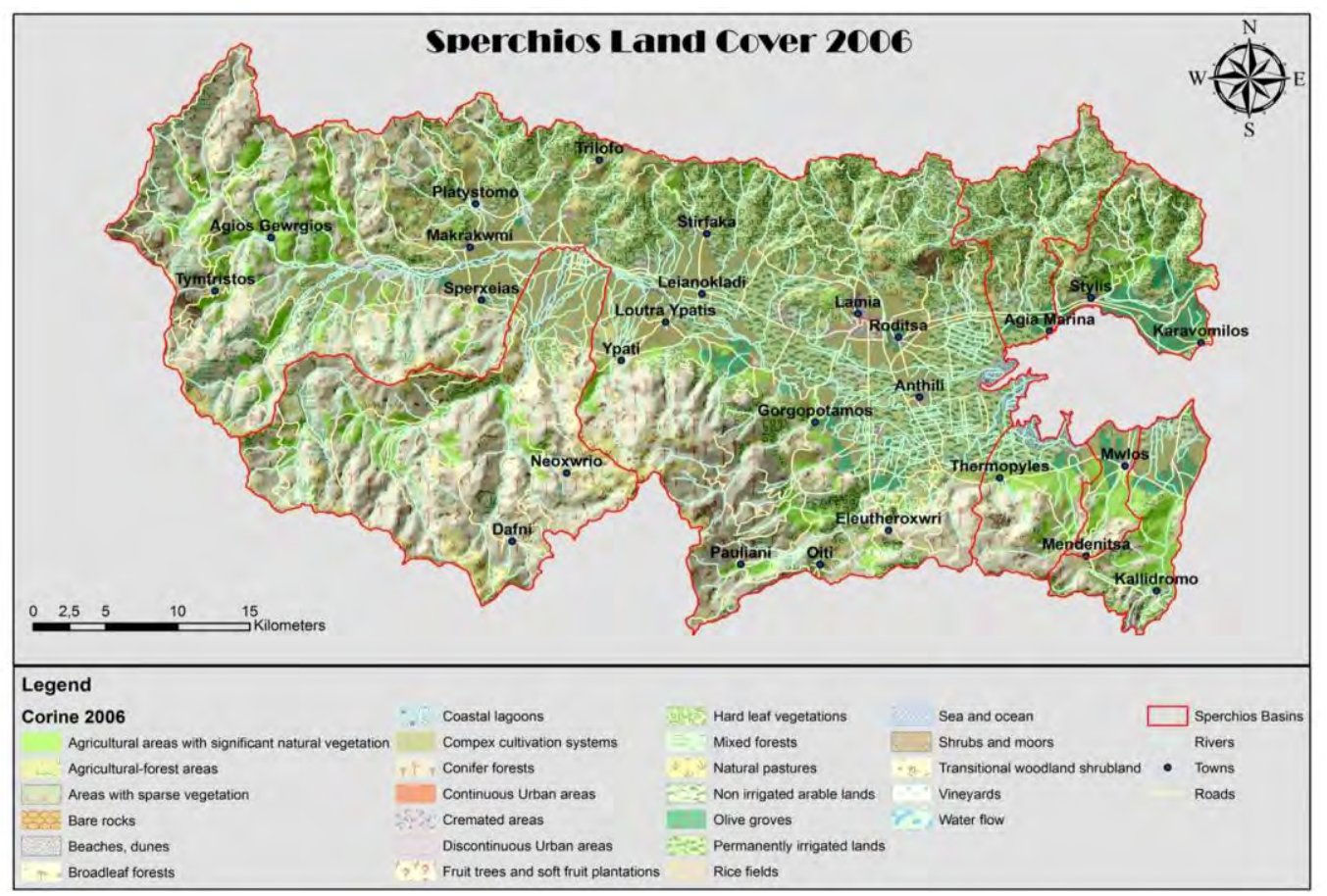

Figure 4: Land Cover/Use map - Corine 2006 (Stathopoulos et. al, 2012). 
Table - Land Cover/Use percentages (Corine 2006).

\begin{tabular}{|l|r|}
\hline \multicolumn{1}{|c|}{ Sperchios Basin Land cover - Land use } & Percentages (\%) \\
\hline Transitional woodland shrubland & 10,04 \\
Broadleaf forests & 8,20 \\
Natural pastures & 7,44 \\
Conifer forests & 13,80 \\
Olive groves & 2,84 \\
Agricultural areas with significant natural vegetation & 8,13 \\
Compex cultivation systems & 12,07 \\
Mixed forests & 3,68 \\
Hard leaf vegetations & 19,67 \\
Non irrigated arable lands & 3,61 \\
Permanently irrigated lands & 6,58 \\
Other various land cover/use & 3,94 \\
\hline
\end{tabular}

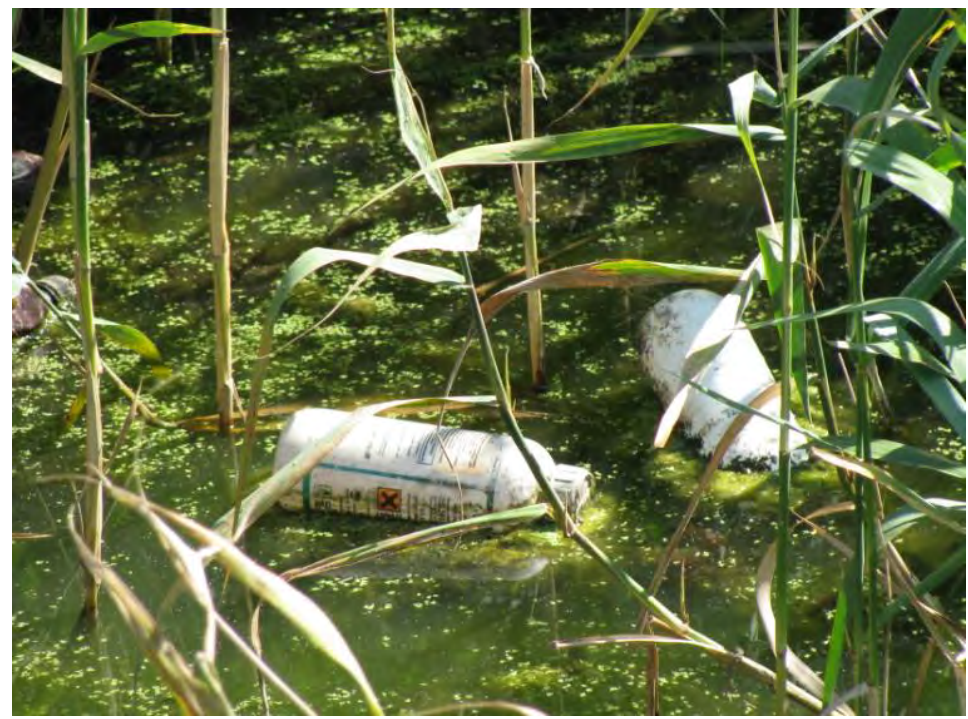

Figure 5 - Pollution from fertilizers in Sperchios River (lowland area).

Based on the analysis of the hydro-chemical data from 99 samples of groundwater during the period from September 2005 up to August 2006, is noted that (Koutsogiannis, 2007):

- The electrical conductivity (EC) ranges between $323-1370 \mu \mathrm{S} / \mathrm{cm}$ with an average value of $680 \mu \mathrm{S} / \mathrm{cm}$. Augmentation of the EC is recorded towards the coastal area, due to the loading of groundwater with salts as it flows and also due to sea intrusion.

- The nitric ions range between $0-155 \mathrm{mg} / \mathrm{l}$ with an average value of $28 \mathrm{mg} / \mathrm{l}$ (the limit of European Union for potable water is $50 \mathrm{mg} / \mathrm{l}$ ). High values come of human activities and mainly because of intense agricultural activity with the application of fertilizers, as well as from the lack of sewage system and use of septic sinks in many areas. Thus per places groundwater becomes improper for potable use.

- Phenomena caused by sea intrusion are detected in the eastern part of Sperchios deltaic area.

- The concentration of $\mathrm{Cl}$ ions ranges between $7-174 \mathrm{mg} / \mathrm{l}$ with an average value of $29 \mathrm{mg} / \mathrm{l}$. 


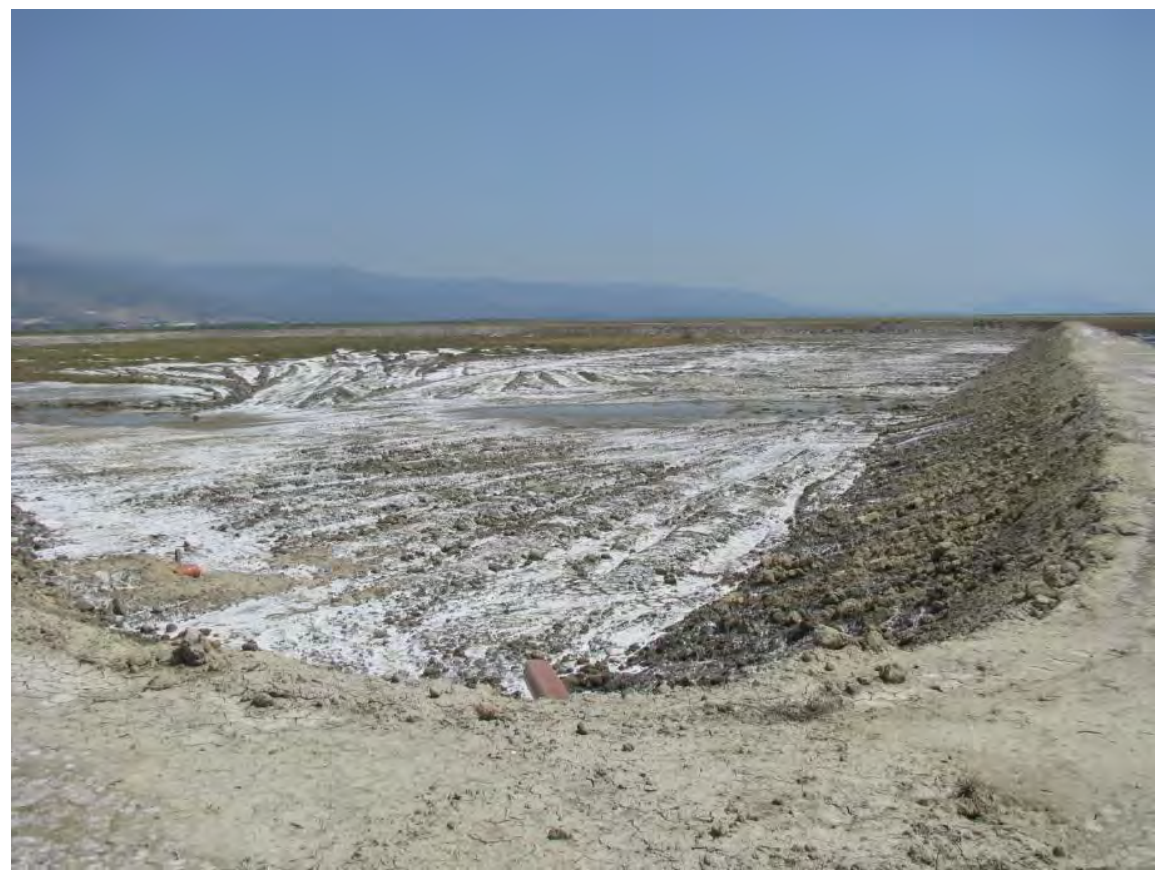

Figure 6 - Obvious soil salinization in Sperchios delta area.

\section{SWOT Analysis}

SWOT analysis (figure 7) is a useful tool for planning development and decision making and has widely been applied to environmental planning and water resource management (AHRD 2001, Baser 2001).

Strengths and weaknesses are factors of the system (internal issues), while opportunities and threats are factors of the external environment (external issues). In other words, a SWOT analysis helps to find the best match between environmental trends (opportunities and threats) and internal capabilities and facilitate a strategic approach to administration (Richards 2001). Concerning the application of SWOT analysis, it is necessary to minimize or avoid both weaknesses and threats. Weaknesses should be converted into strengths (Danca 2000). Likewise, threats should be converted into opportunities.

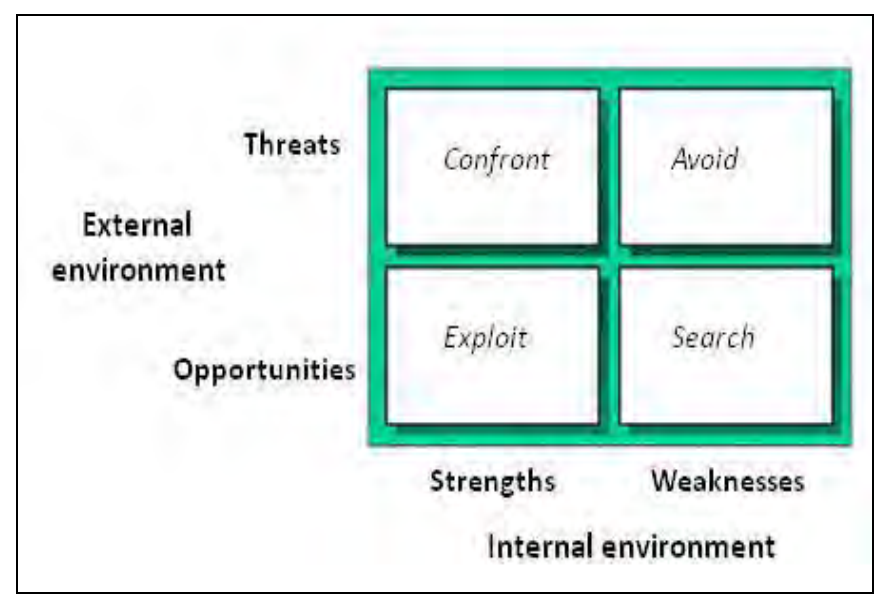

Figure 7 - SWOT analysis diagram.

XLVII, No $2-785$ 
The Strengths of the basin are:

- The capacity of river Sperchios, whose runoff crosses the whole basin, is significant (annual runoff 693,1 $\mathrm{hm}^{3}$ ). (Koutsogiannis, 2007)

- The availability of the surface water deposits during the wet and dry period.

- The existence of recent hydrogeological studies is an advantage for the rational water resource management, as it can provide new data and contribute to the planning of better strategies in order to achieve water sustainability.

- The existence of important thermal-springs in many sites of the basin that can be exploited for social-economic development of the area.

- The existence of karstic aquifers with annual water deposits of about $136 \mathrm{hm}^{3} / \mathrm{yr}$ (Koutsogiannis, 2007).

- The existence of many environmentally protected areas (Natura).

- Water quality in the upper part of Sperchios River, is generally good. The water recharge is rich in quantity and of very good quality, thus improving and renewing, in a sufficient rate, the deteriorated water caused by human activities. Stathopoulos (2008), noticed the degradation of water quality by nitrate pollution and chloride because of the sea intrusion.

- There are biological treatment units in the wider area

The weaknesses of the basin are:

- Increased water demands, mainly during summer period

- The overexploitation of the area's water recourses for irrigative purposes.

- The lack of adequate monitoring data (groundwater levels, quality data, torrents, etc.). Especially, in Sperchios River (one of the most important rivers in Greece) there is no kind of monitoring for quality or discharge.

- The extended use of fertilizers, causing nitrate pollution.

- The salinization of coastal aquifers, mainly due to over-pumping of groundwater for irrigation purposes and also due to natural sea intrusion.

- Quality deterioration of the area's water resources, due to urbanization (urban wastes).

- In the lower part of Sperchios, the water quality is deteriorated

- The total basin is characterized as in high risk for erosion

- In most of the villages there are septic sinks, which cause problems to water quality. The lack of a proper sewage system in the area must be mentioned.

- Water deterioration caused by industrial wastes.

- The periodic flooding of the lowland areas via Sperchios River due to extreme rainfall events.

- Urbanization, construction of public transportation network infrastructure.

The opportunities of the basin are:

- There are many biological treatment units in the area, which doesn't work at this time. The operation of them will help to the proper management of the waste waters.

- The existence of thermal springs. This is a significant factor for the touristic development of the area and the financial regeneration.

- The EU Framework Directive (2000/60/EC). This Directive provides new legislation and opportunities for the sustainable management of water resources.

- The directive requires the establishment of monitoring programs covering groundwater quantitative and qualitative status. 
- Directive 2006/21/EC of the European Parliament and of the Council of 15 March 2006 on the management of waste from extractive industries and amending Directive 2004/35/EC - Statement by the European Parliament, the Council and the Commission.

- There are many protected areas in the basin (Natura), fact that is very important, because the legislation can restrict the environmental pressures in these regions.

- Hydropower plants were proposed for covering the needs of energy in the basin

The threats of the basin are:

- The improper waste treatment, which is a complex problem

- The extensive pumping could cause possible subsidence

- The area's erosion is extended and the sediment yield of the river is increased with various effects to the environment.

- The area is in risk for natural hazards (landslides)

- Cremated areas (forest fire)

- Pollution of Maliakos gulf

- Shrinkage of natural biodiversity in the area

- The climate changes in correlation with the overexploitation of the surface and groundwater resources.

\section{Conclusions}

The main environmental pressures of groundwater resources of Sperchios basin are:

$>$ Urbanization

$>$ Agricultural activities

$>$ Over-exploitation of water resources

$>$ Salinization

$>$ Lack of rational environmental management

$>$ Industrial pollution

According to SWOT analysis it is necessary to minimize the weaknesses and convert the threats to opportunities. In addition, strengths and opportunities should be matched to optimize the water resources of the basin. Based on the SWOT analysis results the following actions are suggested:

$\checkmark$ The reduction of over-pumping in order to preserve the water deposits, which shrink also due to climate changes, will protect the area from landslides and subsidence. This action will aid also in the suspension of sea intrusion and salinization.

$\checkmark$ Proper use of the water treatment plants of the area (optimization of the active ones and operation start for the inactive ones). These actions will increase the water supply of the area and thus the groundwater pumping will be minimized.

$\checkmark$ Adoption of new cultivation methods, in order to reduce fertilizing and preserve the area from desertification.

$\checkmark$ Construction of small interception works along Sperchios river flow, as wells as in the basin's stream network in order to contain water quantities and use them for the area's water needs.

$\checkmark$ Installation of - suitable equipment for monitoring a) the river's discharge, quality, sediment yield, flooding peaks and $b$ ) the water table of coastal drills so that sea intrusion and salinization will be controlled and ameliorate.

$\checkmark$ Implementation of projects concerning the area's sustainable water resources management is considered to be of high importance.

$\checkmark$ Credible implementation of the EU Directive 2000/60/EC.

XLVII. No $2-787$ 


\section{References}

Academy of Human Resources Development 2001. Performing a SWOT analysis, http://www.academyofhrd.org/clsot.htm

Baser O. 2001. SWOT analysis: a practical guide for young managers, http://www.baserler.com.tr/onur/isletme/management\%20skills-swot.htm.

Danca A. 2000. An explanation of the SWOT analysis process, http://www.stfrancis.edu/ba/ghkickul/stuwebs/btopics/works/swot.htm.

Daskalaki P. and Voudouris K. The impacts of the irrational water resources management on the groundwater quality of Greece, http://www.srcosmos.gr/srcosmos/showpub.aspx?aa=8804

Diamantopoulou P. and Voudouris K. 2008. Optimization of water resources management using SWOT analysis: the case of Zakynthos Island,Ionian Sea, Greece, Environ Geol., 54, 197211.

IGME 2010. Recording and evaluating of groundwater's hydrogeological characteristics and the aquifer system of Greece, $3^{\text {rd }}$ Community Support Framework, Athens

Kakavas N. 1984. Hydrological water balance of basin of Sperchios river, Phd Thesis, Athens.

Kallioras A., Pliakas F., Diamantis I., Kallergis G., 2010. SWOT analysis in groundwater resources management of coastal aquifers: a case study from Greece, Water International, Vol. 35, No 4, 425-441.

Koutsogiannis D. 2007. Project plan of water resources management of the country, Ministry of Development - Directory of Water Dynamic and Natural Resources, Athens.

Psomiadis E. 2010. Research of the geomorphological and environmental changes in the hydrological basin of Sperchios River by using new techniques, Phd thesis, Agricultural University of Athens.

Richards H. 2001. Modeling and decision support tools. Department of Engineering, University of Cambridg,. http://www-mmd.eng.cam.ac.uk/people/ahr/dstools/paradigms/swot.htm

Stathopoulos N., Vasileiou E., Charou E., Perrakis A., Kallioras A., Rozos D. and Stefouli M. 2012.Coupling of remote sensing, climate and hydrologic data for assessing coastline changes in R. Sperchios estuary (Maliakos Gulf, Greece), Geophysical Research Abstracts, Vol. 14, EGU2012-9712, 2012 EGU General Assembly 2012, Vienna 22-27 April, Austria. 